Website: https://ojs.unikom.ac.id/index.php/common DOI Jurnal: https://doi.org/10.34010/common

DOI Artikel: https://doi.org/10.34010/common.v4i2.4437

\title{
TINDAKAN KOMUNIKASI DALAM TRADISI MAULUDAN DI DESA KEMUJA KABUPATEN MENDO BARAT PROVINSI KEPULAUAN BANGKA BELITUNG
}

\author{
Rismawaty Rais ${ }^{1}$, Nova Deria ${ }^{2}$ \\ Program Studi Ilmu Komunikasi, Fakultas Ilmu Sosial dan Ilmu Politik, Universitas Komputer \\ Indonesia, Jalan Dipati Ukur 102-116, Bandung, 40132, Indonesia ${ }^{1,2}$ \\ E-Mail: \\ rismawaty@email.unikom.ac.id ${ }^{1}$,nova.deria19@gmail.com²
}

\begin{abstract}
This research was conducted to explain the communication actions in the Mauludan Tradition. The focus of the problem in this study is how the orders, statements, requests, and non-verbal behavior in the Mauludan Tradition in Kemuja Village.

The research method used is a qualitative research method of communication ethnographic studies. The research subjects were the Kemuja Village Community and the number of research informants was 6 (six) people obtained through the snowball techniques and purposive sampling. Data collection techniques through reference books, previous research, internet searching, participant observation, in-depth interviews, and documentation.

The results showed that the people of Kemuja used Bangka Malay as a means of communication. Communicative actions contained in the Mauludan Tradition are the Actions of command: men are obliged to wear Muslim clothes when performing, Statements actions: bring food to the mosque for 2 consecutive days, Action of Request: as a form of gratitude and thanks to Allah SWT and as a respect for ancestors so that their lives are always on the right path. Non-Verbal Behavioral Actions: shaking hands with others as a form of apology and forging ties of friendship, carrying food from house to mosque as a form of mutual cooperation, gratitude for sustenance and sharing, wearing Muslim clothes and fragrances as a form of respect. The act of communication at the Mauludan event must continue to be celebrated so that people's lives are blessed to increase their faith and can continue to maintain cultural authenticity.

The conclusion of this research is that the Communication Actions in the Mauludan Tradition in Kemuja Village runs in a solemn atmosphere and there is an exchange of certain symbols such as in the nganggung activities, the clothes used, and other accessories.
\end{abstract}

Keywords: Communication Ethnography, Communication Actions, Actions of command, Statement Actions, Action of Request, Mauludan Tradition.

\begin{abstract}
Abstrak
Penelitian ini dilakukan untuk menjelaskan mengenai Tindakan Komunikasi dalam Tradisi Mauludan. Fokus masalah dalam penelitian ini yaitu bagaimana perintah, pernyataan, permohonan dan perilaku nonverbal dalam Tradisi Mauludan di Desa Kemuja.

Metode penelitian yang digunakan adalah metode penelitian kualitatif studi etnografi komunikasi. Subjek penelitian adalah Masyarakat Desa Kemuja dan informan penelitian berjumlah 6 (enam) orang yang diperoleh melalui teknik snowball dan purposive sampling. Teknik pengumpulan data melalui referensi buku, penelitian terdahulu, internet searching, observasi partisipan, wawancara mendalam, dan dokumentasi.

Hasil penelitian menunjukan bahwa masyarakat Kemuja menggunakan bahasa melayu Bangka sebagai alat komunikasinya. Tindakan Komunikatif yang terdapat dalam Tradisi Mauludan yaitu tindakan perintah: laki-laki wajib menggunakan baju muslim saat manggung, tindakan pernyataan: membawa makanan ke masjid selama 2 hari berturutturut, Tindakan permohonan: sebagai bentuk rasa syukur dan berterima kasih kepada Allah SWTserta penghormatan kepada leluhur agar hidup mereka selalu dijalan yang benar. Tindakan Perilaku Nonverbal: bersalaman dengan sesama
\end{abstract}


Jurnal Common | Volume 4 Nomor 2 | Desember 2020

Website: https://ojs.unikom.ac.id/index.php/common

DOI Jurnal: https://doi.org/10.34010/common

DOI Artikel: https://doi.org/10.34010/common.v4i2.4437

sebagai bentuk permohonan maaf dan menjalin tali silaturahmi, mengangkat makanan dari rumah ke masjid sebagai bentuk gotong royong, ucapan syukur atas rezeki dan saling berbagi, memakai baju muslim dan wewangian sebagai bentuk penghormatan. Tindakan komunikasi di acara Mauludan harus terus dirayakan agar kehidupan masyarakat mendapat berkah meningkatkan keimanan mereka dan dapat terus menjaga keaslian budaya.

Simpulan dari penelitian ini yaitu Tindakan komunikasi dalam Tradisi Mauludan di Desa Kemuja berjalan dengan suasana khidmat dan terjadi pertukaran simbol-simbol tertentu seperti pada kegiatan nganggung, pakaian yang digunakan, dan kelengkapan lainnya

Kata Kunci: Etnografi Komunikasi, Tindakan Komunikasi, Tindakan Perintah, Tindakan Pernyataan, Tindakan permohonan, Tradisi Mauludan. 
Website: https://ojs.unikom.ac.id/index.php/common

DOI Jurnal: https://doi.org/10.34010/common

DOI Artikel: https://doi.org/10.34010/common.v4i2.4437

\section{Pendahuluan}

Mauludan sejatinya adalah perayaan yang dilakukan oleh masyarakat Desa Kemuja dalam memperingati hari lahir Nabi Muhammad SAW yang jatuh pada 12 Rabiul Awal. Tradisi ini bermula dari kedatangan guru besar, Syekh Abdurrahman Siddiq di pulau Bangka tahun 1898. Beliau bermukim di Bangka untuk mengembangkan ilmunya, berdakwah sambil memulai menulis kitab.

Tradisi Mauludan sangat menarik untuk di teliti, karena dalam setting alamiahnya tradisi Mauludan mengandung unsur-unsur komunikasi yang dikemas dalam suatu budaya dan tradisi di lingkungan masyarakat. Pada konteks ini pola interaksi antar masyarakat akan muncul melalui perilaku, ide, atau gagasan melalui lambang atau simbol karena potensi perilaku akan memunculkan potensi komunikasi, begitupun sebaliknya.

Mauludan sejatinya adalah bentuk penghormatan warga Kemuja terhadap hari kelahiran Nabi Besar, Nabi Muhammad SAW dengan perwakilan dari masyarakat berkumpul di masjid pada malam hari sebelum 12 Rabi'ul Awwal dan membacakan kisah hidup tauladan Nabi Muhammad SAW, memanjatkan salam dan shalawat sepanjang malam. Dilanjutkan dengan ritual doa bersama yang diakhiri santap bersama masyarakat yang disebut dengan tradisi Nganggung guna mempererat tali silahturahmi antar masyarakat, mengenalkan anak cucu mereka dengan nilai-nilai kebudaya sekaligus menjadi sarana menyampaikan pesan sifat kegotong royongan.

Nganggung merupakan tradisi yang dilakukan oleh masyarakat Bangka Belitung, disini masyarakat Kemuja dengan mangangkat sesuatu yang agung dari rumah untuk dimakan bersama-sama, kata Nganggung secara etimologi berasal dari kata "ngang" yang berarti ngangkat atau ngangkut dan kata "gung" yang berarti sesuatu yang agung. Waluyo (2015) menegaskan bahwa tradisi Nganggung bukanlah sebuah tradisi yang berdiri sendiri, namun tradisi nganggung merupakan sebuah paket dari ritual doa dan diakhiri dengan acara santapan bersama. Sebuah paket dari ritual tersebut berisi rangkaian-rangkaian acara agar terwujudnya tradisi Mauludan. Menurut masyarakat Desa Kemuja, Nganggung sendiri merupakan wujud sikap gotong royong dan kebersamaan masyarakat Kemuja.

Tradisi tersebut dilakukan biasanya dilakukan selama dua malam, sampai pada hari 12 Rabi'ul Awwal. Setelah tradisi ini dilakukan, masyarakat desa kemuja melanjutkan perayaan Mauludan dengan lebaran kampung yang sangat meriah serta antusias dan menampilkan tarian khas Bangka yaitu tari campak dengan memainkan alat musik dambus. Segala kegiatan yang dilakukan merupakan salah satu kearifan lokal dari hal adat istiadat, di samping nilai, etika, kepercayaan, hukum, dan aturan-aturan khusus yang terdapat dalam masyarakat Kemuja. Dalam tradisi ini, masyarakat menunjukan suka cita mereka terhadap Tauladan Nabi Muhammad SAW dengan saling berbagi dan bersilahturahmi agar kehidupan dalam masyarakat saling berdampingan dan saling mengasihi. Tradisi Mauludan ini juga sudah dilakukan sejak jaman penjajahan jepang, sehingga tradisi Mauludan sudah menjadi ciri khas dan identitas masyarakat desa Kemuja dan sudah mendarah daging bagi mereka.

Oleh karena itu dapat kita lihat dari tahapan perayaan tradisi Mauludan diatas didalamnya banyak terjadi tindakan komunikasi dan dengan hal tersebut peneliti tertarik untuk mengetahui lebih dalam mengenai tradisi Mauludan yang mana masih dilakukan oleh masyarakat Desa Kemuja dan mereka masih memegang teguh adat istiadat kebudayaan leluhur mereka. Ditambah lagi dengan perayaan Maulid Nabi di Bangka Belitung sendiri yang menjadi tuan rumahnya yaitu di Desa Kemuja dengan Tradisi Mauludan. Berdasarkan wawancara yang dilakukan oleh peneliti mengenai Apa yang membuat Tradisi Mauludan di kemuja ini sangat istimewa bagi masyarakat di Bangka, 
Website: https://ojs.unikom.ac.id/index.php/common

DOI Jurnal: https://doi.org/10.34010/common

DOI Artikel: https://doi.org/10.34010/common.v4i2.4437

menurut Arsah selaku Tokoh Masyarakat Kemuja. "Sudah identitas kita lah kalau maulid ini. Misal, orang Kemuja motong ayam 3 ekor, petaling motong ayam 10 , tetap menang orang kemuja dalam perayaannya. Ya karena sudah namanya tadi dan kita sudah jauh lebih lama merayakan mauludan" (Arsah, 2018).

Keunikan-keunikan dari Tradisi Mauludan di Desa Kemuja ini juga terdapat pada kegiatan melakukan arak arakan Tudung Saji terbesar pada tahun 2017 dengan ukuran berdiameter 7,8 meter dan tinggi mencapai 1,5 meter.

Engkus Kuswarno dalam bukunya
metode etnografi komunikasi juga mengemukakan bahwa: "Etnografi komunikasi melihat perilaku dalam konteks sosiokultural, mencoba menemukan hubungan erat antara bahasa, komunikasi, an konteks kebudayaan dimana peristiwa komunikasi itu berlangsung" (Kuswarno, 2008)

Pada etnografi komunikasi, yang menjadi fokus perhatian adalah apa yang individu dalam suatu masyarakat lakukan atau perilaku, kemudian apa yang mereka bicarakan atau bahasa dan apa ada hubungan antara perilaku dengan apa yang seharusnya dilakukan dalam masyarakat tersebut. Kesimpulan dalam fokus etnografi komunikasi itu yaitu keseluruhan perilaku dalam tema kebudayaan tertentu.

Hymes dalam buku Engkus Kuswarno menjelaskan tentang aktivitas komunikasi yaitu "Aktivitas yang khas dan kompleks, yang di dalamnya terdapat peristiwa-peristiwa khas komunikasi yang melibatkan tindak-tindak komunikasi tertentu dan dalam konteks komunikasi yang tertentu pula" (Kuswarno, 2008:42)

\section{Tinjauan Pustaka dan Kerangka Pemikiran}

\subsection{Tinjauan tentang Komunikasi Ritual}

\author{
Ilmu komunikasi di era sekarang ini \\ memiliki berbagai macam kajian
}

komunikasinya. Salah satunya Komunikasi Ritual. Ilmu komunikasi tidak hanya mempelajari suatu interaksi dengan sesamanya, komunikasi juga mempelajari interaksi dengan tuhan atau leluhurnya yang ditransferkan melalui simbol-simbol dimana pakar keilmuan komunikasi menyebutnya dengan komunikasi ritual.

Menurut Deddy Mulyana dalam bukunya Ilmu Komunikasi Suatu Pengantar memaparkan bahwa: "Komunikasi Ritual dapat dimaknai sebagai proses pemaknaan pesan sebuah kelompok terhadap aktifitas religi dan system kepercayaan yang dianutnnya. Dalam prosesnya selalu terjadi pemaknaan simbol-simbol tertentu yang menandakan terjadinya proses Komunikasi Ritual tersebut. Dalam proses Komunikasi Ritual itu kerap terjadi persainggan dengan paham-paham kegamaan sakral yang kemudiaan ikut mewarnai proses tersebut" (Mulyana: 2005).

Sedangkan menurut William I Gordon yang dikutip oleh Deddy Mulyana: "Komunikasi ritual, komunikasi yang menampilkan perilaku tertentu yang bersifat simbolik dan berkomitmen untuk kembali pada tradisi keluarga, suku, bangsa, negara, ideology dan agama. Komunikasi ritual ini erat kaitannya dengan komunikasi ekspresif" (Gordon dalam Mulyana, 2007)

Rohtenbuhler yang dikutip oleh Andung menguraikan beberapa karakteristik dari ritual itu sendiri sebagai berikut:

1. Ritual sebagai aksi

Ritual merupakan aksi dan bukan hanya sekedar pemikiran atau konsep semata. Dalam kehidupan sehari-hari, mitos adalah salah satu rasionalisasi dari aktifitas ritual. Dengan demikian ritual dipandang sebagai suatu bentuk aksi tidak saja sebagai salah satu cara berpikir. Ritual pun merupakan sesuatu hal dimana orang mempraktekkannya dan tidak saja dipendam dalam benak.

2. Performance (pertunjukan) 
Website: https://ojs.unikom.ac.id/index.php/common DOI Jurnal: https://doi.org/10.34010/common

DOI Artikel: https://doi.org/10.34010/common.v4i2.4437

Ritual dipertunjukkan sebagai suatu bentuk komunikasi tingkat tinggi yang ditandai dengan keindahan (estetika), dirancang dalam suatu cara yang khusus serta memperagakan sesuatu kepada khalayaknya. Karena menekankan pada unsur estetika, pertunjukan ritual mengandung dua karakteristik. Pertama, ritual tidak pernah diciptakan dalam momentum aksi itu sendiri. Sebaliknya, ritual selalu merupakan aksi yang didasarkan pada konsepsi-konsepsi yang ada sebelumnya. Kedua, ritual selalu merupakan pertunjukan untuk orang lain. Pertunjukan tersebut dimaksudkan untuk memperagakan kompetensi komunikasi kepada khalayak.

3. Efektifitas simbol-simbol

Simbol-simbol dalam suatu ritual sangat efektif dan powerful. Kekuatan dari simbol-simbol ritual ini secara jelasnya nampak dalam bentuk ritus. Simbol-simbol ritual selalu berperan dalam semua bentuk ritual. Bahkan, ketika terjadi transformasi sosial yang tidak menampilkan maksud secara eksplisit dari suatu pertunjukan ritual seperti halnya sebuah lagu, tarian, gerakgerik tubuh, doa, penjamuan, kebiasaan dan sebagainya. Simbol-simbol tersebut berfungsi sebagai alat komunikasi.

\section{Keramat}

Banyak ahli menekankan bahwa ritual adalah aksi yang berkaitan dengan keramat atau sakral. Adapun kriteria dari kesakralan itu adalah menayangkut pola aktifitas atau tindakan dari anggota masyarakat. Contohnya, bagaimana masyarakat menyuguhkan dan memperlakukan obyek-obyek yang dianggap sakral. Tindakan semacam ini mencerminkan suatu tendensi betapa pentingnya suatu benda yang disakralkan tersebut dalam kehidupan mereka.

\subsection{Tinjauan tentang Tradisi}

Hal yang paling mendasar dari tradisi adalah adanya informasi yang diteruskan dari generasi ke generasi baik tertulis maupun (sering kali) lisan, karena tanpa adanya ini, suatu tradisi dapat punah.

Secara teminologis perkataan "tradisi" mengandung dalam dirinya suatu pengertian tersembunyi tentang adanya kaitan antara masa lalu dengan masa kini. Ia menunjuk kepada sesuatu yang diwariskan oleh masa lalu tetapi masih berwujud dan berfungsi pada masa sekarang. Tradisi dalam pengertiannya yang paling elementer adalah sesuatu yang ditransmisikan atau diwariskan dari masa lalu ke masa kini (Poespowardojo, 1993).

Koentjaraningrat mendefinisikan tradisi sebagai berikut: "Tradisi adalah sistem aktivitas atau rangkaian tindakan yang ditata oleh adat atau hukum yang berlaku dalam masyarakat yang berhubungan dengan berbagai macam peristiwa yang biasanya terjadi dalam masyarakat yang bersangkutan" (Koentjaraningrat, 1984)

Pengertian-pengertian tradisi yang disampaikan di atas masih mengacu pada pengertian tradisi sebagai "warisan dari masa lalu" sebagai sesuatu yang diterima oleh generasi sekarang dari para pendahulu mereka. Tradisi yang dilakukan dan tetap dilestarikan sampai sekarang karena dianggap memiliki nilai yang benar bagi kehidupan. Para pemikir yang gagasan-gagasannya dikutip dia atas belum memberikan tempat kepada tradisi sebagai sesuatu yang diciptakan.

\subsection{Tinjauan Komunikasi Nonverbal}

Manusia dipersepsi tidak hanya lewat bahasa verbalnya bagaimana bahasanya (halus, kasar, intelektual, mampu berbahasa asing, dan sebagainya), namun juga melalui perilaku nonverbalnya. Menurut Knapp dan Hall isyarat nonverbal, sebagaimana simbol verbal, jarang punya makna denotatif yang tunggal, salah satu faktor yang mempengaruhinya adalah 
Website: https://ojs.unikom.ac.id/index.php/common DOI Jurnal: https://doi.org/10.34010/common

DOI Artikel: https://doi.org/10.34010/common.v4i2.4437

konteks tempat perilaku berlangsung (Mulyana, 2007)

Secara sederhana, pesan nonverbal adalah semua isyarat yang bukan kata-kata. Menurut Larry A. Samovar dan Richard E. Porter menyatakan bahwa "Komunikasi nonverbal mencakup semua rangsangan (kecuali rangsangan verbal) dalam suatu setting komunikasi, yang dihasilkan oleh individu dan penggunaan lingkungan oleh individu, yang mempunyai nilai pesan potensial bagi pengirim atau penerima" (Samovar dan Porter dalam Mulyana, 2007)

Sementara menurut Edward T. Hall "Menamai bahasa nonverbal sebagai 'bahasa diam' (silent language) dan 'dimensi tersembunyi' (hidden dimension) suatu budaya. Disebut diam dan tersembunyi, karena pesan-pesan nonverbal tertanam dalam konteks komunikasi. Selain isyarat situasional dan relasional dalam transaksi komunkasi, pesan nonverbal memberi kita isyarat-isyarat kontekstual. Bersama isyarat verbal dan isyarat kontekstual, pesan nonverbal membantu kita menafsirkan seluruh makna pengalaman komunikasi” (Hall dalam Mulyana, 2007)

\subsection{Komunikasi Sebagai Proses Simbolik}

Komunikasi manusia adalah subjektif dan melibatkan makna. Agar simbol bisa digunakan dalam komunikasi, makna dan tanggapannya haruslah dibuat. Manusia harus belajar pola komunikasi dan makna (Ruben \& Stewart, 2013)

Lambang atau simbol adalah sesuatu yang digunakan untuk menunjuk sesuatu yang lainnya, berdasarkan kesepakatan sekelompok orang. Lambang meliputi kata-kata (pesan verbal), perilaku nonverbal, dan objek yang maknanya disepakati bersama.

Lambang atau simbol adalah salah satu kategori tanda. Hubungan tanda dengan objek dapat juga direpresentasikan oleh ikon dan indeks, namun ikon dan indeks tidak memerlukan kesepakatan. Lambang bersifat sembarang, manasuka, atau sewenag-wenang.
Apa saja bisa dijadikan lambang, bergantung pada kesepakatan bersama-sama. Kata-kata (lisan atau tulisan), isyarat anggota tubuh, makanan dan cara makan, tempat tinggal, jabatan (pekerjaan), olahraga, hobi, peristiwa, hewan, tumbuhan, gedung, alat (artefak), angka, bunyi, waktu, dan sebagainya semua itu bisa menjadi simbol (Mulyana, 2013)

Proses pemberian makna terhadap simbol-simbol yang digunakan dalam berkomunikasi, selain dipengaruhi faktor budaya, juga faktor psikologis, terutama pada saat pesan di decode oleh penerima. Sebuah pesan yang disampaikan dengan simbol yang sama, bisa saja berbeda arti bilamana individu yang menerima pesan itu berbeda dalam kerangka berpikir dan kerangka pengalaman (Spradley, 2007)

Defini diatas berkaitan dengan lambang atau simbol yang disepakati oleh masyarakat di Desa kemuja saat melangsungkan perayaan tradisi Mauludan yaitu melalui bahasa melayu bangka berupa pernyataan atau ujaran, tarian, dan bunyi dari alat musik itu sendiri.

\subsection{Kerangka Pemikiran}

Kerangka pemikiran merupakan pemetaan (mind mapping) yang dibuat dalam Penelitian untuk menggambarkan alur pikir peneliti. Berangkat dari permasalahan penelitian yang berkaitan dengan aktivitas komunikasi, perayaan radisi Mauludan sendiri tidak lepas dari aktivitas komunikasi baik secara verbal dan nonverbal.

Komunikasi dengan menggunakan bahasa verbal sebagai pesan yang disampaikan yang terjadi dalam Tradisi Mauludan seperti Nganggung terdapat ceramah didalamnya menggunakan kata-kata, dengan bahasa lisan. Lalu, komunikasi nonverbal adalah ketika dalam Tradisi Mauludan adanya simbol selain kata-kata seperti penampilan, pakaian, gerakan dan postur tubuh, ekspresi wajah, kontak mata, sentuhan yang sangat khas dan kompleks yang melibatkan tindakan komunikasi tertentu dan dalam konteks tertentu, sehingga proses 
Website: https://ojs.unikom.ac.id/index.php/common DOI Jurnal: https://doi.org/10.34010/common

DOI Artikel: https://doi.org/10.34010/common.v4i2.4437

komunikasi disini menghasilkan peristiwaperistiwa yang khas dan berulang.

Untuk memperkuat peneltian ini, maka peneliti menggunakan teori interaksi simbolik. Interaksi simbolik pertama kali dikemukakan oleh George Herbert Mead yang kemudian dimodifikasi oleh Blumer untuk tujuan tertentu. Interaksi simbolik dalam pembahasannya menunjuk kepada sifat khas dari interaksi antar manusia dalam masyarakat dan hubungan masyarakat dengan individu, interaksi yang terjadi antar individu tersebut berkembang melalui simbol-simbol yang mereka ciptakan.

Etnografi komunikasi memandang perilaku komunikasi sebagai perilaku yang lahir dari integrasi tiga keterampilan yang dimiliki setiap individu sebagai makhluk sosial, ketiga keterampilan itu terdiri dari keterampilan bahasa, keterampilan komunikasi, dan keterampilan budaya. Bahsa hidup dalam komunikasi, bahasa tidak akan mempunyai makna jika tidak dikomunikasikan. Pada etnografi komunikasi terdapat pemaknaan terhadap simbol-simbol yang disampaikan secara verbal maupun nonverbal, sehingga menimbulkan sebuah interaksi dimana didalamnya terdapat simbolsimbol yang memiliki makna tertentu.

Dalam etnografi komunikasi terdapat unsur bahasa yang tidak bisa terpisahkan dalam kajian kebudayaan tersebut. Bahasa menjadi inti dari komunikasi sekaligus sebagai pembuka realitas bagi manusia. Kemudian dengan komunikasi, manusia membentuk masyarakat dan kebudayaannya sehingga bahasa secara tidak langsung turut membentuk kebudayaan pada manusia. Pada etnografi komunikasi terdapat pemaknaan terhadap simbol-simbol yang disampaikan secara verbal maupun nonverbal, sehingga menimbulkan sebuah interaksi yang didalamnya terdapat simbol-simbol yang memiliki makna tertentu.

Untuk mendeskripsikan tindakan komunikasi dalam penelitian ini, maka model penelitian peneliti seperti pada gambar di bawah ini:

Gambar 1. Alur Pikir Peneliti

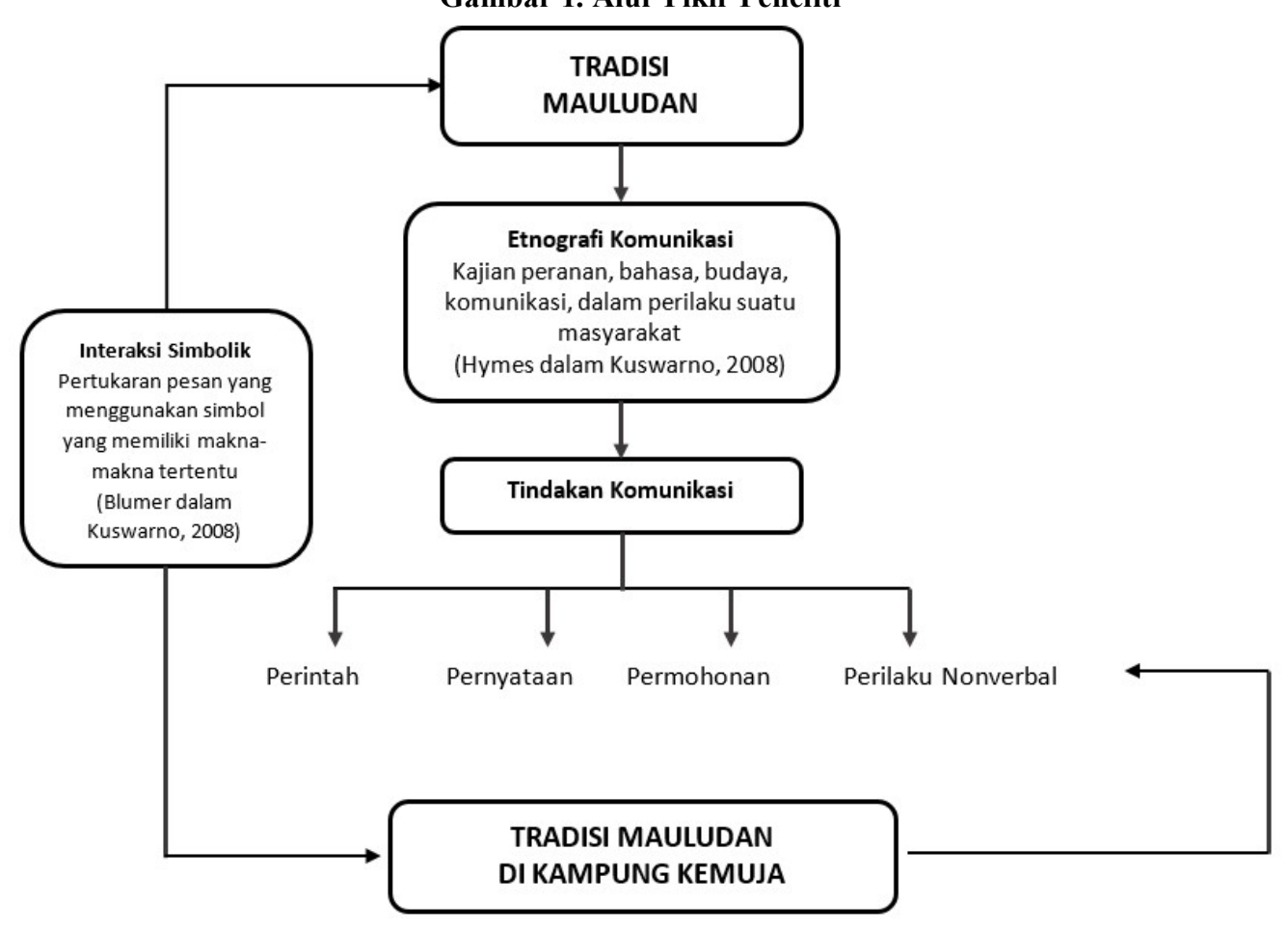


Website: https://ojs.unikom.ac.id/index.php/common

DOI Jurnal: https://doi.org/10.34010/common

DOI Artikel: https://doi.org/10.34010/common.v4i2.4437

\section{Objek dan Metode Penelitian}

Maulid berasal dari bahasa Arab ini yang berarti "tempat kelahiran". Kosa kata ini disematkan pada acara peringatan kelahiran Nabi Muhammad SAW. pada 12 Rabi'ul Awwal yang disebut acara "Maulid Al-Nabi". Sebutan itu pada mulanya disematkan pada acara yang digelar di rumah kelahiran beliau di Mekah, terutama dilakukan para sufi. Maulid Nabi pertama kali diadakan pada masa kekuasaan Ayyubiyah, disana di dapati suatu jenis upacara yang khas, disebut "MAULID", upacara maulid itu dicetuskan oleh ibunya Khalifah Harun Al-Rasyid yaitu Khaizurom (Abdul fatah, 2006)

Tidak ada catatan jelas mulai kapan tradisi untuk memperingati kelahiran Nabi Muhammad SAW. Ini mulai berlangsung dan bagaimana penyebarannya. Yang jelas pada abad pertengahan atau akhir pemerintahan Dinasti Fathimiyyah di Mesir, tradisi tersebut sudah dikenal. Namun tradisi itu hanya dilakukan pada siang hari dan hanya dihadiri para ulama dan pejabat. Ketika dinasti tersebut tumbang, tradisi ini nyaris sirna. Namun, kemudian tradisi tersebut muncul kembali dalam bentuk yang berbeda karena dihidupkan kembali oleh Sultan Muzhaffaruddin Kokburi dari Dinasti Ayyubiyyah pada abad ke-7 Hijriyah atau 13 Masehi.

Tradisi maulid ini kemudian menyebar ke berbagai penjuru dunia Islam, salah satunya Indonesia. Peringatan maulid ini bukan tanpa tantangan. Bahkan, sejak awal kelahirannya sudah banyak ulama yang menilai sebagai bid'ah. Para pendukungnya membela, memang acara itu bid'ah, tetapi bid'ah hasanah (yang baik). Ada juga yang mengajukan hadis pendukung, tapi hadis itu dha'if.

Menurut masyarakat Kemuja malam kelahiran Nabi adalah malam yang sangat mulia. Tidak ada anjuran khusus dalam mengamalkan peringatan tersebut. Umat islam hanya dianjurkan membaca shalawat nabi sebanyak-banyaknya. Shawalat ini sebagai ungkapan rasa cinta kepada Rasul. Tidak hanya shalawat, umat Islam juga dianjurkan sedekah, berbuat kebaikan, mengungkapkan kebahagiaan di hari Maulid Nabi.

Peneliti menggunakan metode penelitian kualitatif, dengan pendekatan studi etnografi komunikasi, teori subtantif yang digunakan yaitu dengan teori interaksi simbolik, dimana teori tersebut digunakan untuk menganalisis aktivitas komunikasi dalam tradisi Mauludan. David Williams dalam buku Lexy Moleong menyatakan: "Penelitian kualitatif adalah pengumpulan data pada suatu latar alamiah, dengan menggunakan metode alamiah, dan dilakukan oleh orang atau peneliti yang tertarik secara alamiah" (Moleong, 2007)

Berbeda dengan definisi diatas Denzin

dan Lincoln dalam buku Creswell mengemukakan bahwa: "Penelitian kualitatif terdiri dari serangkaian praktik-praktik penafsiran material yang membuat dunia menjadi terlihat. Praktik-praktik ini mentransformasikan dunia, mengubah dunia menjadi serangkaian representasi yang mencakup berbagai catatan lapangan, wawancara, percakapan, foto, rekaman dan catatan pribadi. Penelitian kualitatif melibatkan suatu pendekatan penafsiran yang naturalistic dimana peneliti mempelajari benda-benda dilingkungan alamiah, berusaha untuk memaknai atau menafsirkan realitas dalam sudut pandang makna-makna yang diberikan oleh masyarakat" (Lincoln dalam Creswell, 2014)

Dilihat dari konteks yang lebih besar, maka etnografi komunikasi adalah sebuah metode yang berpayung di bawah paradigm konstuktivisme dan di dalam perspektif teoritik interpretivisme. Etnografi merupakan suatu cara bagi peneliti untuk masuk ke dalam lingkungan yang diteliti serta melakukan komunikasi dengan subjek penelitian dalam kerangka konstuktivisme yang berlandaskan pemikiran realitas sosial itu diciptakan dan dilestarikan melalui pengalaman subjektif dari para pelaku sosial. Para pelaku sosial ini dianggap aktif sebagai interpreter dalam 
menginterpretasikan aktivitas simbolik mereka (Zakiah, 2008).

Dalam penelitian ini, informan yang dipilih peneliti adalah Tokoh Adat, Kepala Desa, Wakil Ketua Komite Mauludan, masyarakat asli kemuja, dan pengunjung yang mana mereka dipilih dari berbagai kriteria yang dapat memenuhi kebutuhan informasi bagi peneliti. Peneliti menggunakan teknik snowball dan purposive sampling. Burgess dalam Deddy Mulyana menjelaskan bahwa prosedur sampling bola salju bergantung terutama pada perkenalan pribadi yang menghubungkan peneliti dengan informaninforman yang pada gilirannya menghubungkannya kepada informaninforman berikutnya (Mulyana, 2013). Sedangkan purposive sampling yaitu dimana teknik didasarkan pada pertimbangan bahwa informan harus di anggap khas (typical) sebagai subjek penelitian (Kuswarno, 2008).

Tabel 1. Informan Penelitian Kunci

\begin{tabular}{|c|c|c|}
\hline No & Nama & Keterangan \\
\hline 1. & Suparman & $\begin{array}{c}\text { Tokoh } \\
\text { Masyarakat Kemuja }\end{array}$ \\
\hline 2. & $\begin{array}{r}\text { M. } \\
\text { Kosim }\end{array}$ & $\begin{array}{l}\text { Kepala Desa } \\
\text { Kemuja }\end{array}$ \\
\hline 3. & Hamsi & $\begin{array}{c}\text { Wakil Ketua } \\
\text { Komite Mauludan } \\
2018\end{array}$ \\
\hline
\end{tabular}

Tabel 2. Informan Penelitian Pendukung

\begin{tabular}{|r|r|r|}
\hline No & Nama & Keterangan \\
\hline 1. & Amrina & $\begin{array}{c}\text { Masyarakat } \\
\text { Asli Kemuja }\end{array}$ \\
\hline 2. & Indri & Pengunjung \\
\hline 3. & Elvian & Budayawan \\
\hline
\end{tabular}

\section{Hasil Penelitian dan Pembahasan}

\subsection{Hasil Penelitian}

Penelitian ini menggunakan teknik pengumpulan data melalui wawancara mendalam yang dilakukan secara tatap muka oleh peneliti dengan narasumber, serta observasi partisipan yang diikuti peneliti pada saat perayaan Tradisi Mauludan di Desa Kemuja.

Berdasarkan hasil pengamatan yang peneliti lakukan saat berlangsungnya tradisi Mauludan mengenai Aktivitas Komunikasi Dalam Tradisi Mauludan di Desa Kemuja Kabupaten Mendo Barat Provinsi Kepulauan Bangka Belitung, tradisi Mauludan dalam memperingati hari lahir Nabi Muhammad SAW hingga saat ini masih dilakukan dan dilestarikan secara turun-temurun oleh masyarakat dari generasi ke generasi. Ditambah lagi dengan dukungan dari Pemerintahan Provinsi Kepulauan Bangka Belitung sendiri. Pada saat perayaannya juga di hadiri oleh Gubernur Provinsi Kepulauan Bangka Belitung, Erzaldi yang turut serta mengikuti kegiatan ritual masyarakat yaitu Nganggung di Masjid Rahmatudin. Acara ini dilakukan setiap setahun sekali pada 12 Rabiul Awal.

Tradisi ini merupakan budaya yang wajib dilakukan demi melestarikan budaya dari leluhur masyarakat dan dianggap sakral karena ada beberapa kegiatan seperti Berzanji dan Nganggung yang dianggap oleh masyarakat sebagai penghubung dengan Allah SWT dan Nabi Muhammad SAW. Selain kegiatan ritual, dalam tradisi ini juga ada Festival Seni Budaya Islam Melayu Babel sebagai ajang pelestarian kesenian dan budaya Bangka yang semenjak tahun 2018 kemarin sudah diambil alih oleh Provinsi.

Berdasarkan hasil wawancara yang peneliti lakukan dengan informan serta observasi pertisipan atau pengamatan langsung dilapangan, maka peneliti menganalisa Aktivitas Komunikasi dalam Tradisi 
Website: https://ojs.unikom.ac.id/index.php/common

DOI Jurnal: https://doi.org/10.34010/common

DOI Artikel: https://doi.org/10.34010/common.v4i2.4437

Mauludan di Desa Kemuja Kecamatan Mendo Barat Provinsi Kepulauan Bangka Belitung yang meliputi:

Tindak komunikatif dalam arti nya adalah pernyataan, perintah, permohonan dan perilaku nonverbal. Sehari sebelum perayaan tradisi Mauludan, masyarakat sudah menyiapkan makanan untuk dibawa dalam kegiatan nganggung menyambut maulid di Masjid. Para ibu-ibu sudah mulai menyediakan makanan untuk diisi di dulang dan akan dibawa oleh kepala keluarga dan anak lelaki untuk dimakan bersama di masjid dan diiringi doa bersama. Dalam hal ini, Hamsi mengatakan: "Sebelum hari $\mathrm{H}$ ya hari ini, kami sudah melakukan nganggung, masyarakat sudah nganggung menyambut maulid ke Masjid. Jadi nganggung dilakukan dua kali, pada saat magrib tadi, dan besoknya pada perayaan maulid tapi di pagi hari. Beberapa masyarakat juga membacakan kitab berzanji" (Wawancara, 11 juni 2019).

Sejalan dengan observasi peneliti dilapangan, bahwa nganggung ini hanya bisa dilakukan oleh para lelaki sehingga peneliti hanya dapat melihat kegiatan dari luar dan mengandalkan apa yang disampaikan oleh informan. Sejalan dengan yang disampaikan Suparman kepada peneliti, bahwa: "Nganggung ini memang dilakukan oleh pihak laki-laki ya. Karena dari kisah para leluhur juga, memang lelaki yang membawa makanan ke suatu tempat perkumpulan mereka dulu lalu kan diarahkan ke masjid. Untuk para ibu-ibu dan anak perempuan mereka bertugas memasak dan menyiapkan makanan yang akan dibawa. Nganggung sendiri berasal dari kata ngang yang berarti ngangkat dan gung yang berarti agung. Jadi secara sederhana nganggung ini mengangkat sesuatu yang agung. Mereka membawa makanan ke masjid sebagai bentuk rasa syukur mereka atas rezeki yang telah diberikan oleh Allah. Nah nanti kan di masjid kita tidak akan makan lauk dari dulang kita, nanti dioper-oper seperti itu, jadi nanti kita saling berbagi. Intinya sebagai bentuk rasa syukur atas rezeki” (Wawancara, 11 juni 2019).

Mengenai pernyataan Suparman di atas, peneliti masih kurang memahami kaitannya nganggung dengan mauludan, sehingga peneliti bertanya kepada Elvian selaku budayawan Bangka yang mengetahui budaya asli Bangka mengenai nganggung, beliau menjelaskan bahwa: "Nganggung itu kan awalnya tadi kan luapan kegembiraan ketika panen padi sejarahnya. Ketika kegiatan nganggung itu dirayakan untuk hari besar agama itu juga termasuk luapan kegembiraan. Misalnya maulud itu kan luapan kegembiraan pada hari kelahiran Nabi Muhammad SAW. Ya kegembiraan, penghormatan dan luapan kegembiraan pada sesuatu yang agung. Jadi, nganggung juga sebenarnya bukan hanya luapan suka cita, tapi juga untuk duka cita" (Wawancara, 12 juni 2019).

Terkait dengan baju muslim dan kain sarung yang digunakan masyarakat dalam kegiatan nganggung, peneliti mencoba mencari tau dengan menanyakan kepada informan. Peneliti bertanya kepada Hamsi, dan beliau menjawab: "Kalau nganggung ya pasti kita memakai baju muslim dan kain sarung ya, tapi terkadang anak muda jarang mau pakai kain sarung jadi memakai celana panjang namun bukan celana jeans seperti itu ya. Kaya celana bahan lah. Untuk hal tersebut sebenarnya sudah aturan sih, kan kita ke masjid, dan ini acara ke agamaan, pasti harus sopan. Ya bagaimana tauladan Nabi kita saja dalam berpakaian sebenarnya. Ada juga yang memakai gamis kan, semuanya boleh-boleh saja asal tetap baju muslim. Jika memakai jeans kan nanti kita susah gerak kan" (Wawancara, 11 juni 2019)

Pernyataan tersebut sesuai dengan apa yang peneliti amati, bahwa memang masyarakat pada umumnya merayakan tradisi Maulid ini menggunakan baju muslim. Selain itu peneliti juga menanyakan tentang kegiatan berzanji yang diadakan sesudah kegiatan nganggung pada tradisi Mauludan ini, Suparman, beliau memaparkan bahwa: 
Website: https://ojs.unikom.ac.id/index.php/common

DOI Jurnal: https://doi.org/10.34010/common

DOI Artikel: https://doi.org/10.34010/common.v4i2.4437

"Berzanji itu sendiri kan sebuah kisah cerita dalam bahasa arab tentang maulid, tentang kelahiran nabi. Artinya kan mulai ciptaan dari nur nabi Muhammad ni. Asal muasal dari atoknya, turun ke baknya, nurun ke mak nya cahaya nabi Muhammad ini. Dari baru lahir seperti yang diceritakan semalam kan dan tadi pagi juga ada, sampai nabi Muhammad ini diangkat menjadi Rasul. Nah nanti kalau sudah berumur $50^{\text {th }}$ ceritanya ke dalam Isra' Mi'raj. Jadi berzanji ini cerita dalam bahasa arab dilagukan seperti kita membaca al-quran ada syair lagunya. Tapi nanti kalau riwayat kelahiran nabi ini terjemahan dari berzanji lagi. Lalu berurutan membaca riwayat nabi, lalu doa selamat, shalawat, doa tahlilan kepada orang tua yang sudah meninggal, seperti itu. Jadi kita membaca ini ya seperti pengingat lah mengenai Baginda Nabi Muhammad kita, bagaimana seorang yang sangat mulia kan. Nah dengan kita membaca ini, kita berharap semoga kita anak cucu kita bisa mengikuti tauladan Beliau, dan menjadi anak yang baik budi pekerti nya, baik agamanya. Seperti itulah" (Wawancara, 11 juni 2019).

\subsection{Pembahasan}

Pembahasan ini berfokus kepada aktivitas tindakan komunikasi dalam tradisi Mauludan di desa Kemuja Kabupaten Mendobarat Provinsi Kepulauan Bangka Belitung, dimana pelaksanaannya masih memperlihatkan aktivitas komunikasi yang khas dalam setiap prosesnya dan pelaksanaan kegiatan dalam tradisi tersebut. Aktivitas komunikasi sendiri menurut Hymes dalam buku etnografi komunikasi Engkus Kuswarno 2008, menyatakan: Aktivitas yang khas atau kompleks, yang didalamnya terdapat peristiwa-peristiwa khas komunikasi yang melibatkan tindak-tindakan komunikasi tertentu dan dalam konteks yang tertentu pula (Kuswarno, 2008:42).

Definisi diatas membuktikan bahwa tradisi Mauludan di Desa Kemuja ini merupakan aktivitas yang khas dan sejak dahulu diteruskan dari generasi ke generasi dari para pendahulu mereka dan sejak dulu memang sudah dilakukan dengan berbagai kegiatan seperti Berzanji, Nganggung, Festival Seni Budaya Melayu Islam Bangka Belitung, dan Lebaran kampung. Aktivitas khas tersebut tetap berkaitan dengan ajaran agama yang mereka anut yaitu agama Islam. aktivitas yang khas ini dilakukan setahun sekali tepat pada jatuhnya tanggal 12 Rabbiul Awal.

Perayaan tradisi Mauludan di Kemuja ini mempunyai makna mendalam bagi masyarakat Kemuja. Pelaksanaan tradisi ini sangat erat kaitannya dengan budaya masyarakat kemuja yang secara sejarah pun tidak dapat dihilangkan. Diadakannya tradisi ini merupakan bentuk ungkapan kegembiraan masyarakat terhadap hari Lahir Nabi Muhammad SAW atas segala tauladan dan pelajaran hidup serta ilmu agama yang telah disebarkan. Tradisi mauludan dirayakan oleh masyarakat juga sebagai ajang pelestarian budaya asli mereka agar selalu lestari. Lebih dalam lagi, tradisi ini memiliki makna bahwa kita sesama manusia yang maih diberi rezeki harus dapat dan saling berbagi, menghormati, dan menjaga tali silahturahmi.

Kepercayaan masyarakat Kemuja yang sudah ditanamkan sejah dahulu ini membuat tradisi ini terus bertahan meskipun dihadapi perubahan zaman. Untuk mempertahankannya pun, masyarakat selalu mengembangkan kegiatan-kegiatan hiburan dalam perayaannya namun segala nilai budaya dan islami tetap dipertahankan.

Berdasarkan hasil pengamatan peneliti selama mengikuti perayaan Tradisi Mauludan di Desa Kemuja, aktivitas dalam rangkaian kegiatan tradisi Mauludan ini memiliki maksud dan tujuan yaitu untuk meluapkan rasa syukur dan rasa gembira dalam memperingati hari lahir Nabi Muhammad SAW dan juga ungkapan terimakasih kepada Allah SWT serta menghargai leluhurnya supaya dalam kehidupan mereka selalu diberikan keberkahan dan rezeki serta dituntun hidupnya agar menjadi manusia yang berakhlak baik. 
Website: https://ojs.unikom.ac.id/index.php/common DOI Jurnal: https://doi.org/10.34010/common

DOI Artikel: https://doi.org/10.34010/common.v4i2.4437

Perilaku-perilaku yang diperlihatkan oleh masyarakat dalam setiap kegiatannya ini menunjukan bahwa tradisi mauludan sangat berkaitan dengan aktivitas tindakan komunikasi. Terlihat dari berbagai macam aktivitas yang khas yang akan peneliti bahas lebih terperinci pada sub bab selanjutnya.

Tindakan komunikatif merupakan bentuk perintah, pernyataan, permohonan dan perilaku nonverbal. Kali ini peneliti akan membahas serta menganalisis tindakan komunikatif dalam aktivitas komunikasi tradisi mauludan di Desa Kemuja. Untuk membahas tindakan komunikatif, Bentuk perintah dan pernyataan yang terdapat dalam aktivitas komunikasi dalam tradisi mauludan ini yaitu kepala keluarga dan anak lelaki yang membawa makanan ke Masjid dalam kegiatan nganggung. Setiap rumah membawa satu nampan beserta dulang yang berisikan lauk pauk sekali sebelum perayaan Mauludan dan sekali pada saat hari perayaan mauludan. Setelah kegiatan nganggung diiringi doa bersama selesai, dilanjutkan dengan membacakan kitab berzanji.

Selain itu kepala keluarga dan anak lelaki yang mengikuti kegiatan tersebut wajib menggunakan baju muslim, begitu pula untuk acara kegiatan lain-lainnya untuk seluruh masyarakat. Seperti yang sudah peneliti jelaskan sebelumnya, bahwa segala kegiatan dan atribut yang masyarakat Kemuja gunakan pada perayaan tradisi ini merupakan suatu bentuk penghormatan dan ucapan syukur. Sehubung dengan kepercayaan mereka Islami, maka segala kegiatan dan penampilan mereka harus sopan sesuai dengan syariat islam agar mereka benar-benar mencerminkan segala teladan yang telah diajarkan oleh Nabi Muhammad.
Tradisi mauludan ini harus selalu dilakukan oleh masyarakat setahun sekali tanpa terkecuali karena sudah menjadi warisan oleh para leluhur dan guru-guru besar mereka terdahulu. Bilamana tidak dilaksanakan, mereka akan merasakan perasaan kehilangan di hidup mereka. Oleh sebab itu, masyarakat kemuja harus selalu turut berpartisipasi dalam melestarikan tradisi ini agar selalu mendapatkan berkah dan menguatkan iman mereka terhadap Yang Maha Kuasa.

Untuk bentuk permohonan dalam tradisi mauludan ini sama dengan apa yang telah peneliti jabarkan pada komponen fungsi dan tujuan pada sub bab sebelumnya, yaitu sebagai bentuk penggambaran suka cita masyarakat terhadap hari kelahiran Nabi Muhammad SAW atas segala perjuangan beliau dalam membenahi kehidupan di dunia ini. Sedangkan tujuan diadakannya tradisi ini adalah untuk penghormatan serta rasa terimakasih kepada Syekh Abdurrahman Siddiq yang telah mengajarkan dan membimbing masyarakat untuk lebih mengenal Islam. Selain itu juga merupakan ungkapan terimakasih serta penghormatan kepada para leluhur dan guru besar. Selanjutnya untuk bentuk perilaku nonverbal telah dipaparkan dalam komponen isi pesan dalam pembahasan peristiwa komunikasi.

Tindakan komunikatif ini kemudian peneliti gambarkan dalam sebuah model yang dapat menjelaskan bagaimana proses tindakan komunikatif dalam aktivitas komunikasi tradisi Mauludan di Desa Kemuja yang saling berkaitan sehingga dapat dipahami secara keseluruhan. Berikut model tindakan komunikatif. 
Website: https://ojs.unikom.ac.id/index.php/common DOI Jurnal: https://doi.org/10.34010/common

DOI Artikel: https://doi.org/10.34010/common.v4i2.4437

Gambar 1. Model Tindakan Komunikatif

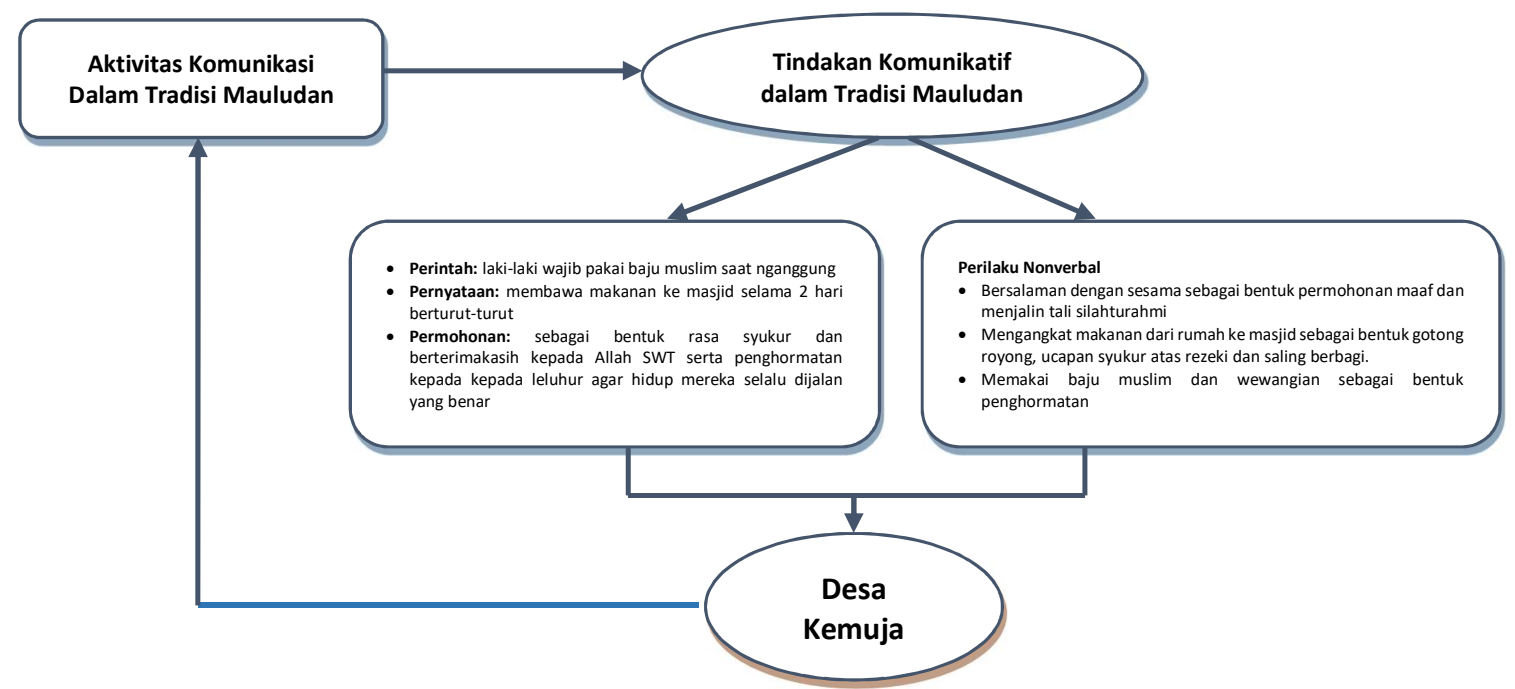

Tradisi mauludan di Desa Kemuja ini merupakan suatu bentuk luapan kegembiraan dan rasa suka cita masyarakat kepada hari Nabi Muhammad SAW serta bentuk penghormatan masyarakat Kemuja kepada guru-guru besar mereka terdahulu dan para leluhurnya. Tradisi ini dilakukan karena para nenek moyang mereka dulu sudah jauh lebih dulu merayakan dan memberikan perhatian yang lebih terhadap hari lahir Nabi. Tradisi Mauludan tersebut memperlihatkan komunikasi verbal dan nonverbal yang ditampilkan oleh masyarakat Kemuja.

Melalui tradisi ini, masyarakat Kemuja menjadikannya sebagai media untuk berkomunikasi dengan Tuhan dan Nabi Muhammad (komunikasi transedental) serta para pendahulu mereka. Hal tersebut dibungkus dalam bentuk pembacaan doa dan kitab berzanji serta shalawatan. Doa-doa tersebut ditujukan agar semua seluruh kegiatan masyarakat untuk melaksanakan tradisi ini berjalan dengan baik tanpa hambatan.

Alat komunikasi yang sering digunakan masyarakat Kemuja adalah bahasa. Menurut pandangan peneliti, masyarakat Kemuja merupakan masyarakat yang Komunikatif. Mereka berbicara bahasa yang sama dengan masyarakat bangka pada umumnya yaitu melayu Bangka, namun setelah peneliti amati di lapangan, sekalipun bahasa utama mereka adalah bahasa melayu Bangka, tetapi mereka tetap memiliki ke khasan sendiri baik itu dari segi logat dan pengucapan huruf vocal. Masyarakat disana pun tidak malu untuk menggunakan bahasa Indonesia dengan baik jika diperlukan.

\section{Kesimpulan}

Tindakan komunikatif merupakan bentuk perintah, pernyataan, permohonan dan perilaku nonverbal. Bentuk pernyataan maupun perintah yang ada dalam tradisi Mauludan ini harus selalu dilakukan oleh masyarakat Kemuja agar dapat memperkuat iman mereka, selalu diberikan keberkahan dan rezeki yang melimpah serta ajang pelestarian budaya asli Bangka. Selain itu, tradisi ini sebagai bentuk penghormatan kepada para leluhur mereka yang sudah mengajarkan anak cucu untuk selalu berbuat kebaikan. Bentuk perilaku noverbal yang terdapat pada tradisi Mauludan ini adalah gerakan tarian, gesture tubuh masyarakat, dan busana yang dipakai oleh masyarakat yang memiliki makna tertentu. 


\section{Daftar Pustaka}

Craswell, John W. 2010. Research Design, Pendekatan Kualitatif, Kuantitatif, dan Mixed. Yogyakarta: Pustaka Pelajar.

Kuswarno, Engkus. 2008. Etnografi Komunikasi, Bandung: Widya Padjajaran

Moleong, Lexy J. 2007. Metodologi Penelitian Kualitatif. Bandung: Remaja Rosdakarya.

Mulyana, Deddy. 2005. Ilmu Komunikasi Suatu Pengantar. Bandung: Remaja Rosdakarya
2007. Ilmu Komunikasi Suatu Pengantar. Bandung: Remaja Rosdakarya

\section{Metodologi} Penelitian Kualitatif. Bandung: Remaja Rosdakarya.

Waluyo, M. E. 2015. "Nilai-nilai dan Makna Simbolik Tradisi Nganggung Di Desa Petaling Propinsi Kepulauan Bangka Belitung". Jurnal Kajian Kebudayaan. 10 (1), 1-15. 